\title{
The Japan Municipal Bond Yield Curve: 2002 to the Present
}

\author{
Takahiro Hattori $^{1} \&$ Hiroki Miyake ${ }^{2}$ \\ ${ }^{1}$ Nomura Securities Co., Ltd. Tokyo, Japan \\ ${ }^{2}$ Faculty of Law and Letters, Ehime University, Ehime, Japan \\ Correspondence: Hiroki Miyake, Faculty of Law and Letters, Ehime University, Ehime, Japan. Tel: \\ 81-89-927-9236. E-mail: mcnnns77@gmail.com
}

Received: March 13, 2016

Accepted: April 5, 2016

Online Published: May 25, 2016

doi:10.5539/ijef.v8n6p118

URL: http://dx.doi.org/10.5539/ijef.v8n6p118

\begin{abstract}
The aim of this paper is to present the par yield curve for Japan's Municipal Bonds, by examining daily data from 2002 to the present. Moreover, this paper contributes to current literature by making available for the first time additional long-run market data on Japan's Municipal Bonds, and thereby enabling economists and practitioners to analyze the large municipal bond market of Japan in detail. We also investigate the fit of the well-known parametric and spline methods in their standard measures, and are able to show that the spline method does, in fact, fit well as in previous studies. In keeping with our aim to make these data more widely available, we posted the data on the following website and expect to update this regularly: http://www.monnns77.net.
\end{abstract}

Keywords: term structure of interest rates, par yield curve, municipal bond market, Japan

\section{Introduction}

Japan's bond market is one of the largest and most advanced in the world. Moreover, in this market, Japan's local municipalities are the second largest bond source. As of the end of September 2015, Japan's outstanding municipal bonds amounted to 74.5 trillion yen ( $\$ 621$ billion), which exceeded all corporate bonds and other public bonds. (Note 1) Compared with advanced Western countries, Japan's municipal bond market has been the largest among unitary countries (Hattori \& Miyake, 2015).

In addition, more and more local governments finance initiatives through the bond market. The scale of Japan's municipal bond market has increased from 59.7 trillion to 74.5 trillion yen in the last 10 years. This equates to a growth rate of $24 \%$, which is larger than the growth in either the corporate bond or the other public bond market. (Note 2) There are two main reasons for this. First, Japan's fiscal system has become more decentralized and as a result, local governments need to raise more money through external financial markets. Second, Japan's local governments have shifted their financing from borrowing from commercial banks to generating funds through bonds issuance.

For this reason, we believe that Japan's municipal bond market is a very important analysis subject, not only for academia but also for business participants in the financial market. The purpose of this study is to estimate Japan's municipal bond yield curve, looking at a daily frequency. Needless to say, the level of yield and its term structure are the most fundamental information necessary for an analysis of the bond market as well as the municipal bond market. The yield curve is reflected in investors' evaluations of local governments, and is one of the most important data sources for the financial market as well as public finance. However, as far as we know, most previous studies estimating the yield curve have focused on the national government bond market. Our estimation here may be the first pioneering effort targeting the sub-sovereign bond market that includes municipal bonds.

In estimating the yield curve, Japan's municipal bond market has some desirable characteristics when compared to other advanced countries. Among these, Japan's local governments issue bonds with high frequency and regularity. For example, Tokyo metropolitan, the largest issuer in Japan's municipal bond market, issues a 10 -year, publicly offered municipal bond every month. In addition, it issues bonds with every other maturity, such as 5, 7, 20, 30 year, at least once a year. As a result, 168 publicly offered municipal bonds issued by Tokyo metropolitan remained in the secondary market at the end of 2015 (excluding those with less than one year maturity). At the same time, there are nine issuers with more than 100 issues remaining in the municipal bond 
market, (Note 3) and another 10 issuers with more than 50 remaining issues. (Note 4) These local governments issue bonds regularly, at least every two or three months. The large number of remaining issues means that we have many samples available for estimating the yield curve. The regular issuing of bonds increases the liquidity of the municipal bond market. Both points are important for the robustness of our estimation result.

Based on Gürkaynak, Sack, and Wright (2007) and Kikuchi and Shintani (2012), our curve fit uses two estimation models, that is, Svensson (1994) and Steeley (1991). The Bank for International Settlements (BIS, 2005) clearly underscores the wide use of Svensson (1994) in estimating the government bond yield curve in advanced countries. Nelson and Siegel (1987), the original model of Svensson (1994), has currently attracted attention in the macro-finance field. In terms of the B-spline (basis spline) model based on Steeley (1991), Kikuchi and Shintani compared the yield estimation models for Japan's government bonds and found that the B-spline model was the best suited. This conclusion falls within our estimation in this study.

Moreover, we have provided our estimation result, including the estimated yield curve of each local government's issuing bond and the number of remaining issues, on our website, which will be updated regularly. (Note 5) Bloomberg L.P., the well-known financial market data source, has already estimated Japan's municipal bond yield curve. However, the number of local governments we include in our estimation is over 40 and in contrast to Bloomberg's data, our estimation term is longer, from 2002 to the present. (Note 6) Moreover, we are making our results publically available through our website (a subscription is required to access the Bloomberg data). Finally, our estimation methodology is concretely based on the academic literature. This enables other third parties to test our results.

As in Gürkaynak et al. (2007), our estimation result will be updated regularly. This can thereby help academia in Japan and in other countries as well as individuals working in Japan's financial markets.

The remainder of this paper is organized as follows. Section 2 briefly summarizes the two yield curve estimation models. Section 3 describes the sample data employed in our yield curve estimation. Section 4 presents our estimation fitness of the estimated yield curve. Section 5 presents our conclusion.

\section{The Yield Curve Models}

As mentioned, many methods for interpolating the yield curve from the market prices of coupon-bearing bonds have been developed in previous studies. According to Gürkaynak et al. (2007), one approach can be classified as the spline-based method. This approach involves a large number of estimated parameters and is considered as one of the more flexible methods. (Note 7) Another approach, classified into parametric forms, involves a smaller number of parameters and is considered more rigid. The former approach has been used by McCulloch (1975, 1990), Steely (1991), Fisher, Nychka, and Zervos (1995), and Waggoner (1997). The latter approach has been used by Nelson and Siegel (1978) and Svensson (1995).

BIS (2005) summarizes the estimation methods used by the central bank in terms of the governments bonds, and shows that these two methods are widely used at many central banks. Some of the studies compare several estimation methods such as Ioannides (2003) for U.K. government bonds and Kalev (2004) for Australian government bonds.

The previous studies of the Japan government bond [JGB] curve include Komine et al. (1989), Oda (1996), Kawasaki and Ando (2005), Fujii and Takaoka (2007), and Kikuchi and Shintani (2012). Kikuchi and Shintani compare multiple estimation methods and conclude that Steeley's (1991) method, which tries to fit the discount curve using B-spline, is the best to interpolate the JGB curve.

In this study, we estimate the yield curve of Japan's municipal bonds based on Svensson (1994) and Steeley (1991). The BIS (2005) shows that the parametric approach, such as Svensson (1994), is utilized by many central banks. In addition, Gürkaynak et al. (2007) who provide and update estimated data quarterly, is widely referenced by academia and practitioners alike. On the other hand, Kikuchi and Shintani (2012) show that Steeley's (1991) method, which interpolates the discount factor based on the B-spline method, is the best fit among the multiple methods when it comes to the JGB.

Our study provides and updates par yields estimated based on Svensson (1994) and Steeley (1991). As Gürkaynak et al. (2007) mention, a trader may care about how a specific security is priced but a macroeconomist may be more interested in understanding the fundamental determinants of the yield curve. One of the important aims here is to provide long-run data for analysts working in the different areas. Therefore, we present the par yield estimated by two different methods. 


\subsection{Svensson (1994)}

The first approach is based on Svensson (1994), who models the forward rate $(\mathrm{f}(\mathrm{x}))$ for the six parameters according to the following functional form. $\mathrm{x}$ is the remaining maturity and $\alpha_{0}, \alpha_{1}, \alpha_{2}, \alpha_{3}, \alpha_{4}, \alpha_{5}$ are the parameters to be estimated.

$$
f(x)=\alpha_{0}+\alpha_{1} \exp \left(-x / \alpha_{3}\right)+\alpha_{2}\left(x / \alpha_{3}\right) \exp \left(-x / \alpha_{3}\right)+\alpha_{4}\left(x / \alpha_{5}\right) \exp \left(-x / \alpha_{5}\right)
$$

This model is an extension of the Nelson and Siegel (1987) model. Therefore, we refer to this as the NSS (Nelson-Siegel-Svensson) functional form. Equation (1) could be converted into the discount function (d(x)).

$$
\begin{aligned}
d(x)=\frac{1}{x} \int_{0}^{x} f(s) d s=\alpha_{0}+ & \alpha_{1}\left(\frac{1-\exp \left(-\frac{x}{\alpha_{3}}\right)}{\frac{x}{\alpha_{3}}}\right)+\alpha_{2}\left(\frac{1-\exp \left(-\frac{x}{\alpha_{3}}\right)}{\frac{x}{\alpha_{3}}}-\exp \left(-\frac{x}{\alpha_{3}}\right)\right) \\
& +\alpha_{4}\left(\frac{1-\exp \left(-\frac{x}{\alpha_{5}}\right)}{\frac{x}{\alpha_{5}}}-\exp \left(-\frac{x}{\alpha_{5}}\right)\right)
\end{aligned}
$$

\subsection{Steeley (1991)}

The second approach is based on Steeley's (1991) model, which estimates the discount function (d(x)) using a B-spline function.

$$
d(x)=\sum_{k=-3}^{n_{k n o t}-1} B(k, x) \alpha_{k}
$$

$\mathrm{B}(k, x)$ is the B-spline function. $\alpha_{k}$ is the parameter to be estimated. In the spline model, we have to set a sequence of points known as knot points. Steeley sets the knots points as $u_{-3}<\cdots<u_{n_{k n o t}}<u_{n_{k n o t}+1}<$ $u_{n_{k n o t}+2}<u_{n_{k n o t}+3} . \mathrm{B}(k, x)$ is recursively defined as shown in equation (4) below.

$$
\begin{gathered}
B(k, x)=B_{1}(k, x):=\left\{\begin{array}{c}
1, u_{k} \leq x \leq u_{k+1} \\
0, \text { otherwise }
\end{array}\right. \\
B(k, x)=B_{D}(k, x)=\frac{u_{D+k}-x}{u_{D+k}-u_{k+1}} B_{D-1}(k+1, x)+\frac{x-u_{k}}{u_{D+k-1}-u_{k}} B_{D-1}(k, x) \text { for } D>1
\end{gathered}
$$

Steeley (1991) and Kikuchi and Shintani (2012) set D = 4 in Equation (4). Equation (3) and $d(0)=1$ provide Equation (5).

$$
\sum_{k=-3}^{n_{k n o t}-1} B(k, 0) \alpha_{k}=1
$$

We refer to this as the BS (B-spline) functional form.

One of the difficulties is how to set the knots. In terms of the JGB context, Kikuchi and Shintani (2012) set these in annual increments from year -2 through year 32. Fujii and Takaoka (2007) set the number of knots with $\sqrt{L_{t}}$ ( $L_{t}$ : number of bonds) and divided each interval by setting knots that had almost the same number of bonds. This paper focuses on Japan's municipal bonds and some local governments did not have enough bonds to use the methodology of Kikuchi and Shintani (2012), therefore, we follow Fujii and Takaoka (2007) in the setting of the knots.

\subsection{Estimating the Yield Curve Model}

The price of a coupon bearing bond (which has a semi-annual coupon payment (c/2) and matures in $\mathrm{x}$ years) is as below in equation (6).

$$
\hat{P}_{t}=\sum_{i=1}^{2 x}(c / 2) d_{t}(i / 2)+100 d_{t}(x)
$$

The face value is $100 \mathrm{JPY}(\mathrm{c} / 100$ is the coupon rate). We can compute the par yield of time $t$, given by,

$$
y_{t}^{p}=\frac{2\left(1-d_{t}(x)\right)}{\sum_{i=1}^{2 x} d_{t}(i / 2)}
$$

$d_{t}(x)$ represents time t's discount rate in $x$ years.

We define this price as the theoretical price (model implied price). We use the residual sum of the squares of errors between the bond actual market prices and the theoretical prices to estimate the parameters of NSS and BS. 
According to the previous studies, the objective function for minimization is as follows:

$$
\begin{aligned}
& \hat{\theta}_{1}=\arg \min _{\theta_{1}} \sum_{i=1}^{N}\left(P_{i}-\hat{P}_{i}\right)^{2} \\
& \hat{\theta}_{2}=\arg \min _{\theta_{2}} \sum_{i=1}^{N}\left(\frac{P_{i}-\hat{P}_{i}}{D_{i}^{M}}\right)^{2}
\end{aligned}
$$

$\mathrm{N}$ is the number of observed bonds, $P_{i}$ is the observed price of the coupon bond, $\hat{P}_{i}$ is the theoretical prices (model implied prices) of the coupon bond. $D_{i}^{M}$ is the modified duration. In (9), the inverse of the modified duration is weighted, converting the objective function into the sum of the squared deviations between the observed and the model-implied yields to maturity.

In BS, equation (8) is used as the objective function, as in Fujii and Takaoka (2007) and Kikuchi and Shintani (2012). On the other hand, in NSS, equation (9) is used as the objective function according to the following. Weighting prices by the inverse duration are used to get the better fitness of the longer bond yields, as in Kladivko (2010). Thus, we use equation (8) for the objective function in BS and equation (9) for the objective function in NSS.

\section{Data Set}

In this study, we estimated the publicly offered municipal bond yield curve. Local governments in Japan issue municipal debt not only by issuing bonds, but also by borrowing from commercial banks or through the Fiscal Investment and Loan Program [FILP], managed by the central government. Some local governments issue private-placement bonds. However, we did not include the prices and yields of this municipal debt because of the difficulty of getting information about these in the secondary market and the differences between bank loans and bonds.

We estimated the yield curve by each local government at a daily frequency. Among about 1,700 local governments in Japan, our estimation focused only on those with at least six publicly offered municipal bonds remaining in the secondary market that satisfied our requirements explained below. (Note 8).

Bond issues sold nationwide. We excluded publicly offered municipal bonds mainly sold to local citizens in the area of the issuer. Such bonds are called "citizen participatory-type bonds" or "mini bonds." Their prices and yields are usually not the same as those of nationwide, publicly offered municipal bonds.

Non-callable bond issues. In Japan's municipal bond market, callable bonds, variable rate bonds, discount bonds, or revenue bonds are rarely or never issued. All of the sample issues in our study have the same characteristics, excluding their price, coupon rate, and maturity.

Bond issues with more than one year to maturity. As in previous studies, we excluded municipal bond issues with short maturity because their price quotes often do not represent their real prices.

As of the end of 2015, 42 local governments, (24 prefectures, one metropolitan, and 17 cities) out of a total of 55 issuing public nationwide bonds, were able to satisfy these requirements (Table 1). This means that most local governments that issue the publicly offered municipal bonds nationwide could be covered in our study. (Note 9) We have also included an estimation of the "Joint Local Government Bond" yield curve. This represents bonds co-issued by two or more local governments with jointly negotiated issuance terms, like the Länder-Jumbo municipal bond in Germany.

\begin{tabular}{|c|c|c|c|c|c|}
\hline \multicolumn{3}{|c|}{ Prefectures } & \multicolumn{3}{|c|}{ Cities and Joint Local Government Bonds } \\
\hline Issuer & Estimation Term & Number of Issues & Issuer & Estimation Term & Number of Issues \\
\hline Aichi Prefecture & $\begin{array}{l}\text { August } 2002 \\
\text { - December } 2015\end{array}$ & 136 & Chiba City & $\begin{array}{l}\text { November } 2005 \\
\text { - December } 2015\end{array}$ & 17 \\
\hline Chiba Prefecture & $\begin{array}{l}\text { August } 2002 \\
\text { - December } 2015\end{array}$ & 95 & Fukuoka City & $\begin{array}{l}\text { August } 2002 \\
\text { - December } 2015\end{array}$ & 53 \\
\hline Fukui Prefecture & $\begin{array}{l}\text { April } 2012 \\
\text { - December } 2015\end{array}$ & 21 & Hamamatsu City & $\begin{array}{l}\text { January } 2013 \\
\text { - December } 2015\end{array}$ & 8 \\
\hline Fukuoka Prefecture & $\begin{array}{l}\text { August } 2002 \\
\text { - December } 2015\end{array}$ & 100 & Hiroshima City & $\begin{array}{l}\text { December } 2003 \\
\text { - December } 2015\end{array}$ & 26 \\
\hline Fukushima Prefecture & March 2008 & 12 & Kawasaki City & August 2002 & 60 \\
\hline
\end{tabular}

Table 1. Local governments included in the sample 


\begin{tabular}{|c|c|c|c|c|c|}
\hline & - December 2015 & & & - December 2015 & \\
\hline Gifu Prefecture & $\begin{array}{l}\text { October } 2011 \\
\text { - December } 2015\end{array}$ & 9 & Kitakyushu City & $\begin{array}{l}\text { December } 2003 \\
\text { - December } 2015\end{array}$ & 33 \\
\hline Gunma Prefecture & $\begin{array}{l}\text { November } 2009 \\
\text { - December } 2015\end{array}$ & 20 & Kobe City & $\begin{array}{l}\text { August } 2002 \\
\text { - December } 2015\end{array}$ & 49 \\
\hline Hiroshima Prefecture & $\begin{array}{l}\text { December } 2002 \\
\text { - December } 2015\end{array}$ & 65 & Kyoto City & $\begin{array}{l}\text { August } 2002 \\
\text { - December } 2015\end{array}$ & 56 \\
\hline Hokkaido Prefecture & $\begin{array}{l}\text { August } 2002 \\
\text { - December } 2015\end{array}$ & 92 & Nagoya City & $\begin{array}{l}\text { August } 2002 \\
\text { - December } 2015\end{array}$ & 77 \\
\hline Hyogo Prefecture & $\begin{array}{l}\text { August } 2002 \\
\text { - December } 2015\end{array}$ & 122 & Niigata City & $\begin{array}{l}\text { December } 2012 \\
\text { - December } 2015\end{array}$ & 9 \\
\hline Kagoshima Prefecture & $\begin{array}{l}\text { November } 2008 \\
\text { - March } 2015\end{array}$ & 4 & Okayama City & $\begin{array}{l}\text { February } 2015 \\
\text { - December } 2015\end{array}$ & 6 \\
\hline Kanagawa Prefecture & $\begin{array}{l}\text { August } 2002 \\
\text { - December } 2015\end{array}$ & 122 & Osaka City & $\begin{array}{l}\text { August } 2002 \\
\text { - December } 2015\end{array}$ & 93 \\
\hline Kumamoto Prefecture & $\begin{array}{l}\text { July } 2007 \\
\text { - December } 2015\end{array}$ & 13 & Saitama City & $\begin{array}{l}\text { December } 2008 \\
\text { - December } 2015\end{array}$ & 9 \\
\hline Kyoto Prefecture & $\begin{array}{l}\text { March } 2003 \\
\text { - December } 2015\end{array}$ & 67 & Sakai City & $\begin{array}{l}\text { December } 2010 \\
\text { - December } 2015\end{array}$ & 15 \\
\hline Miyagi Prefecture & $\begin{array}{l}\text { March } 2006 \\
\text { - December } 2015\end{array}$ & 16 & Sapporo City & $\begin{array}{l}\text { August } 2002 \\
\text { - December } 2015\end{array}$ & 61 \\
\hline Nagano Prefecture & $\begin{array}{l}\text { September } 2004 \\
\text { - November } 2010\end{array}$ & 4 & Sendai City & $\begin{array}{l}\text { February } 2006 \\
\text { - September } 2010\end{array}$ & 4 \\
\hline Niigata Prefecture & $\begin{array}{l}\text { November } 2004 \\
\text { - December } 2015\end{array}$ & 18 & Shizuoka City & $\begin{array}{l}\text { November } 2013 \\
\text { - December } 2015\end{array}$ & 6 \\
\hline Oita Prefecture & $\begin{array}{l}\text { November } 2011 \\
\text { - December } 2015\end{array}$ & 9 & Yokohama City & $\begin{array}{l}\text { August } 2002 \\
\text { - December } 2015\end{array}$ & 107 \\
\hline Okayama Prefecture & $\begin{array}{l}\text { December } 2010 \\
\text { - December } 2015\end{array}$ & 15 & $\begin{array}{l}\text { * Joint Local } \\
\text { Government Bond }\end{array}$ & $\begin{array}{l}\text { September } 2003 \\
\text { - December } 2015\end{array}$ & 108 \\
\hline Osaka Prefecture & $\begin{array}{l}\text { August } 2002 \\
\text { - December } 2015\end{array}$ & 173 & & & \\
\hline Saitama Prefecture & $\begin{array}{l}\text { August } 2002 \\
\text { - December } 2015\end{array}$ & 105 & & & \\
\hline Shimane Prefecture & $\begin{array}{l}\text { March } 2012 \\
\text { - December } 2015\end{array}$ & 14 & & & \\
\hline Shizuoka Prefecture & $\begin{array}{l}\text { August } 2002 \\
\text { - December } 2015\end{array}$ & 118 & & & \\
\hline Tochigi Prefecture & $\begin{array}{l}\text { December } 2013 \\
\text { - December } 2015\end{array}$ & 8 & & & \\
\hline Tokushima Prefecture & $\begin{array}{l}\text { December } 2013 \\
\text { - December } 2015\end{array}$ & 8 & & & \\
\hline Yamanashi Prefecture & $\begin{array}{l}\text { November } 2012 \\
\text { - December } 2015\end{array}$ & 9 & & & \\
\hline Tokyo Metropolitan & $\begin{array}{l}\text { August } 2002 \\
\text { - December } 2015\end{array}$ & 168 & & & \\
\hline
\end{tabular}

Our data for the municipal bond quotes, maturities, and coupon rates came from the Japan Securities Dealers Association [JSDA] and its "Reference Statistical Prices [Yields] for OTC Bond Transactions." JSDA collects on a daily basis bonds quotes from 18 main securities firms. These quotes include national government bonds, corporate bonds, and municipal bonds. The data cover the average, median, highest, and lowest quotes of each bond issue based on JSDA's aggregate data. The data are available starting August 2, 2002. Thus, our estimation term is from that point to December 30, 2015.

\section{Results}

\subsection{Example of Yield Curve Fit}

Figures 1 and 2 show the actual yields and par yield, estimated by NSS and BS. Figure 1 shows the curve of the 
Tokyo Metropolitan Bond and Figure 2 the curve of Joint Local Government Bonds on January 5, 2015. These figures show that the fitness of the NSS model is suited in the short and mid terms. On the other hand, the BS method fits particularly well throughout, including the longer term (over 20 years).

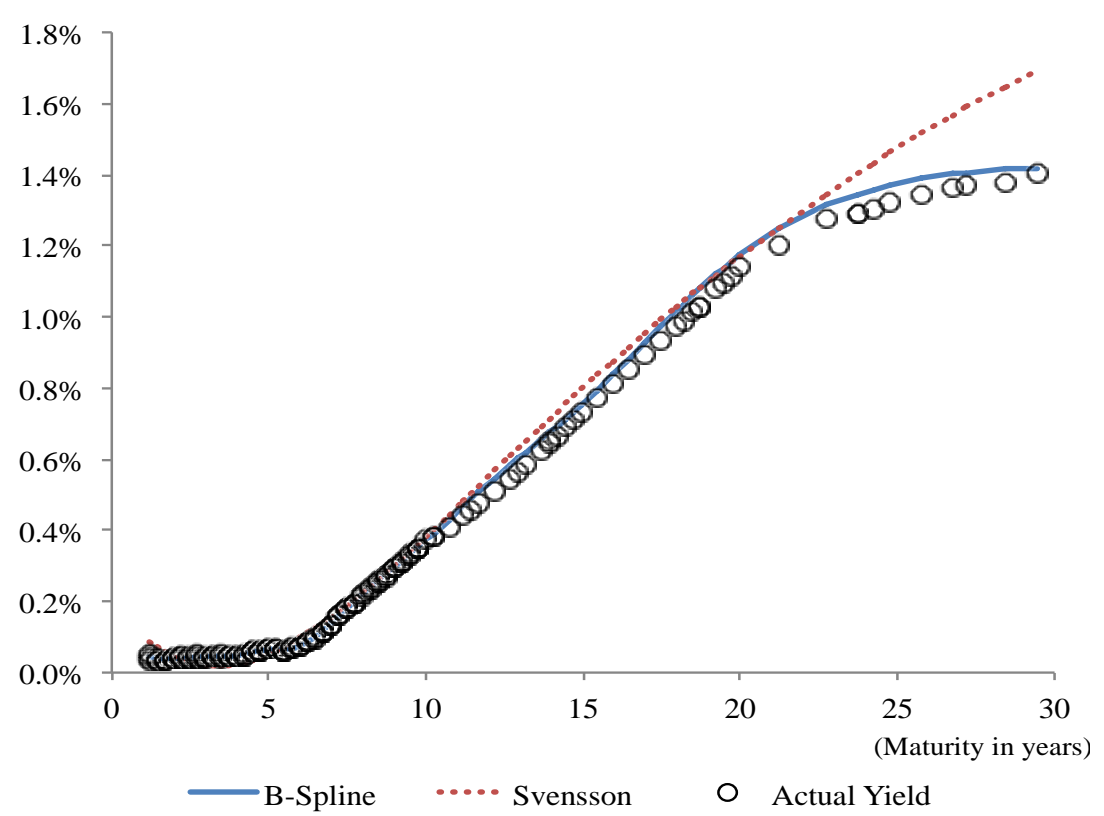

Figure 1. The par-yield curve of Tokyo metropolitan bond on January 5, 2015

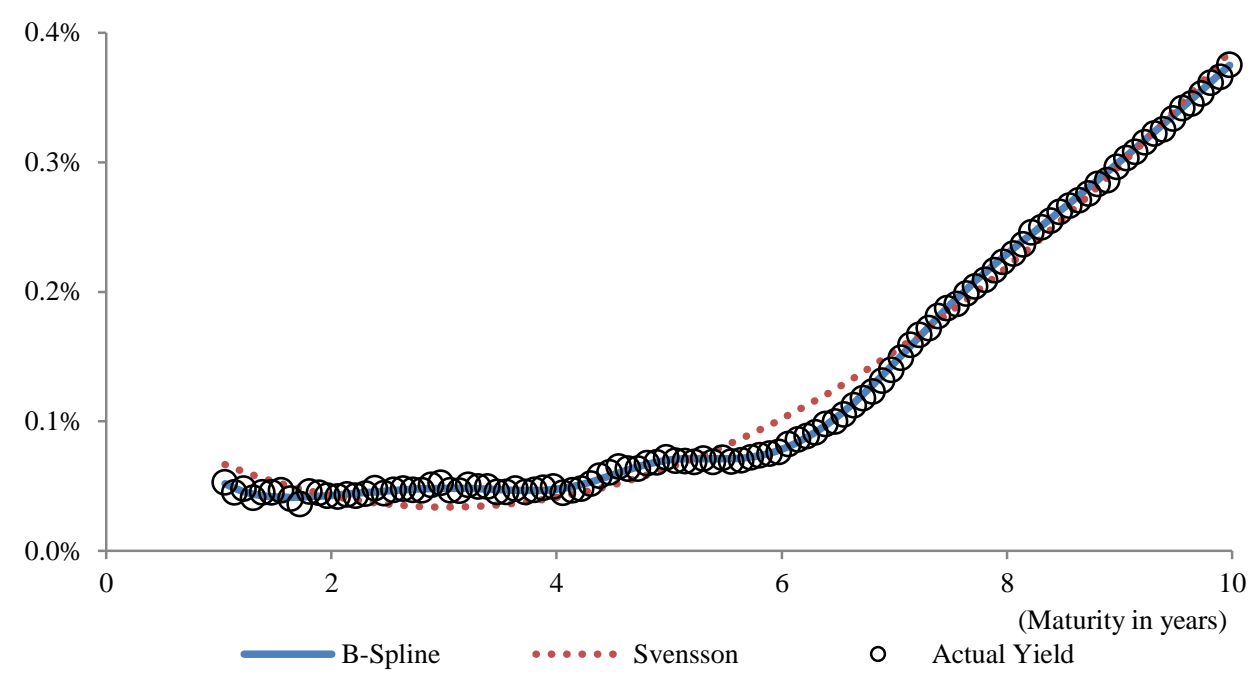

Figure 2. The par-yield curve of Joint Local Government Bond on January 5, 2015

\subsection{Error Measure}

To check the fitness of the NSS and BS methods, we use the estimation error, which can be expressed as the difference between the actual prices and model-implied prices. To capture how well the NSS and BS approach fit the curve, we use the root mean squared error (RMSE) and the maximum absolute error (MaxAE). The RMSE and the MaxAE are calculated as follows:

$$
R M S E=\sqrt{\frac{1}{N} \sum_{i=1}^{N}\left(y_{i}-\hat{y}_{i}\right)^{2}}
$$




$$
\operatorname{Max} A E=\max _{i}\left\{\left|y_{i}-\hat{y}_{i}\right|\right\}, i=1, \ldots, N
$$

In (10) and (11), $\mathrm{N}$ is the number of observed bonds, $y_{i}$ is the actual (observed) yield to maturity, and $\hat{y}_{i}$ is the par yield estimated with NSS and BS. Another measure of fitness could be considered and if you analyze the government bonds or interest rate swap, the smoothness of the forward rate should also be carefully treated. (Note 10) However, the par yield or the (actual) yield is generally more often used in the municipal bonds market, whereas the forward rate is rarely used. Besides, focusing on the par yield or the (actual) yield is considered the standard approach when comparing the fitness of two or more yield curve estimation methods (Ioannides, 2003; Kikuchi \& Shintani, 2012), which we use in this paper.

Figures 3 and 4 show the time series of RMSE and MaxAE of the Tokyo Metropolitan Bond based on BS and NSS. This shows that BS fits better than NSS, which is consistent with the results of Kikuchi and Shintani (2012). Notably, the RMSE of the BS model is quite small over the entire sample term, at around $0.01 \%$, and the MaxAE is around $0.02 \% \sim 0.06 \%$, which is still small. The RMSE and MaxAE of the BS and NSS model increased in 2008 because the shape of the yield curve became distorted by the financial crisis.

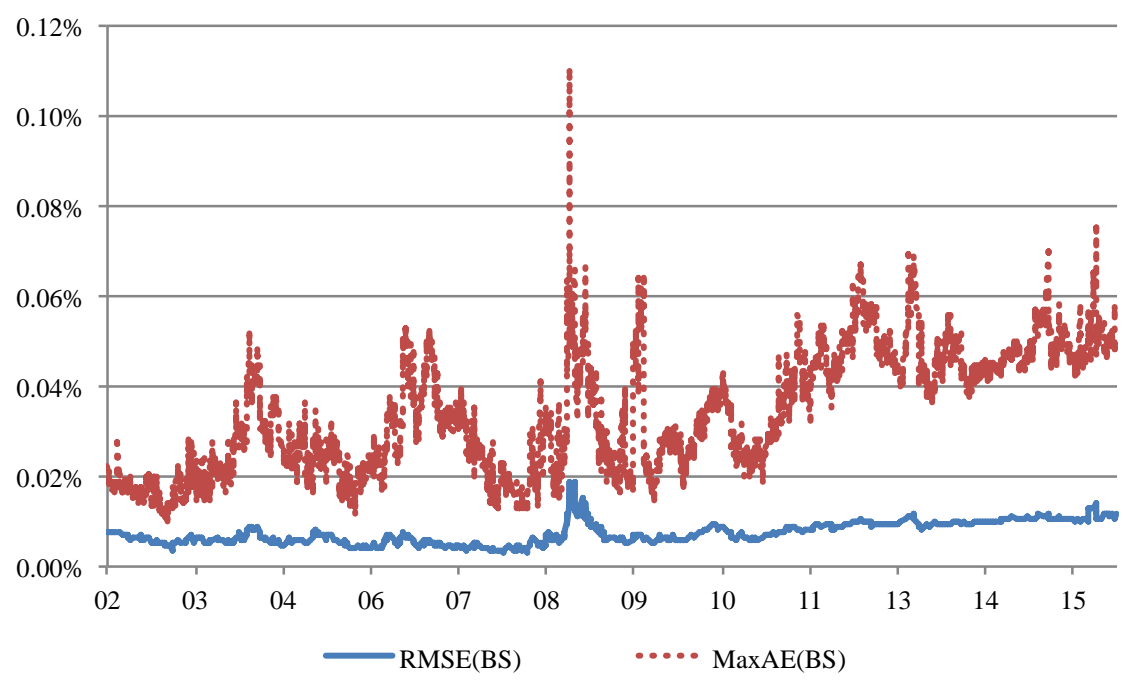

Figure 3. RMSE and MaxAE of Tokyo metropolitan bond based on BS method

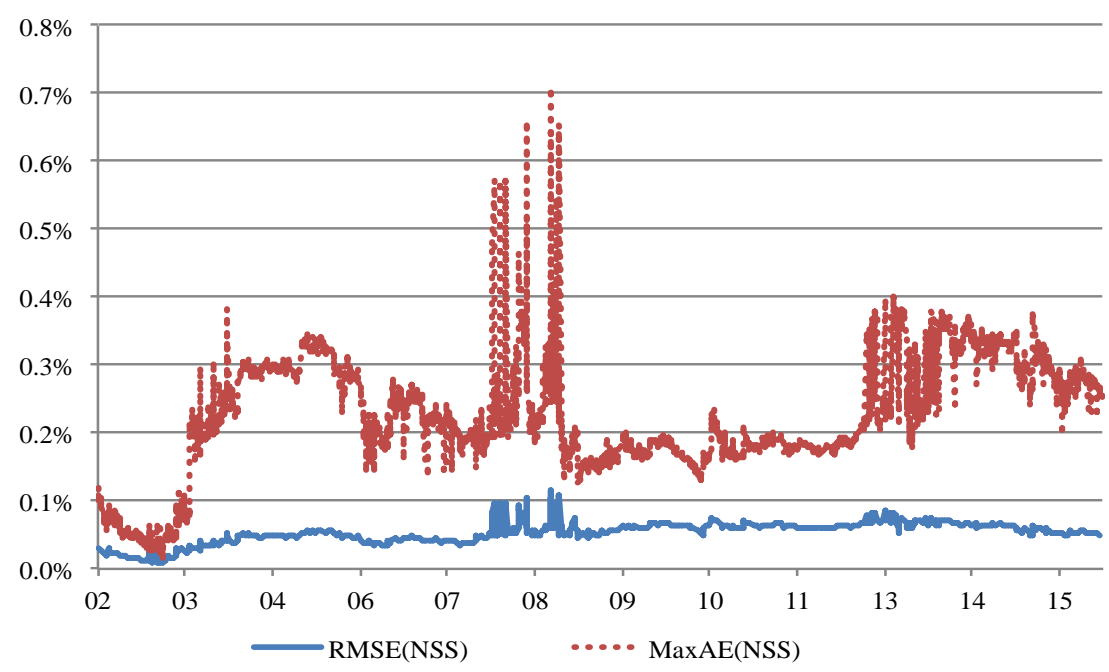

Figure 4. RMSE and MaxAE of Tokyo metropolitan bond based on NSS method

Table 2 shows the mean of the RMSE and the MaxAE for each local government based on the BS and the NSS 
model, using times series data from August 2002 to December 2015 (the data are included when N is 6 or more). The table shows that the fit of the BS model is better than the NSS model. In the BS model, the RMSE is basically less than $0.01 \%$, although there are some exceptions, and the MaxAE is around $0.01 \sim 0.03 \%$, which is still small. On the other hand, in the NSS model, the RMSE of some of the issuers is around $0.01 \%$, although some RMSEs, such as for Tokyo Metropolitan, are over 0.05\%. Notably, the MaxAE of the NSS model is quite large. The MaxAE of some of the issuers is over $0.1 \%$.

Table 2. Mean of the RMSE and MaxAE of all municipal bonds sampled

\begin{tabular}{|c|c|c|c|c|c|c|}
\hline \multirow[b]{2}{*}{ Issuer } & \multicolumn{2}{|c|}{ BS model } & \multicolumn{2}{|c|}{ NSS model } & \multicolumn{2}{|c|}{ Difference } \\
\hline & RMSE(a) & $\operatorname{MaxAE}(\mathrm{b})$ & RMSE (c) & $\operatorname{MaxAE}(\mathrm{d})$ & $\operatorname{RMSE}(\mathrm{a}-\mathrm{c})$ & $\operatorname{MaxAE}(b-d)$ \\
\hline Aichi Prefecture & $0.007 \%$ & $0.026 \%$ & $0.042 \%$ & $0.144 \%$ & $-0.035 \%$ & $-0.118 \%$ \\
\hline Chiba Prefecture & $0.007 \%$ & $0.025 \%$ & $0.036 \%$ & $0.107 \%$ & $-0.029 \%$ & $-0.082 \%$ \\
\hline Fukumi Prefecture & $0.008 \%$ & $0.022 \%$ & $0.035 \%$ & $0.086 \%$ & $-0.027 \%$ & $-0.064 \%$ \\
\hline Fukuoka Prefecture & $0.008 \%$ & $0.028 \%$ & $0.047 \%$ & $0.148 \%$ & $-0.039 \%$ & $-0.120 \%$ \\
\hline Fukushima Prefecture & $0.006 \%$ & $0.012 \%$ & $0.014 \%$ & $0.028 \%$ & $-0.008 \%$ & $-0.015 \%$ \\
\hline Gifu Prefecture & $0.007 \%$ & $0.017 \%$ & $0.019 \%$ & $0.032 \%$ & $-0.011 \%$ & $-0.015 \%$ \\
\hline Gumma Prefecture & $0.010 \%$ & $0.024 \%$ & $0.043 \%$ & $0.101 \%$ & $-0.033 \%$ & $-0.077 \%$ \\
\hline Hiroshima Prefecture & $0.008 \%$ & $0.027 \%$ & $0.036 \%$ & $0.101 \%$ & $-0.028 \%$ & $-0.074 \%$ \\
\hline Hokkaido Prefecture & $0.005 \%$ & $0.017 \%$ & $0.021 \%$ & $0.070 \%$ & $-0.017 \%$ & $-0.053 \%$ \\
\hline Hyogo Prefecture & $0.007 \%$ & $0.030 \%$ & $0.038 \%$ & $0.144 \%$ & $-0.031 \%$ & $-0.114 \%$ \\
\hline Kagoshima Prefecture & $0.003 \%$ & $0.008 \%$ & $0.009 \%$ & $0.016 \%$ & $-0.005 \%$ & $-0.008 \%$ \\
\hline Kanagawa Prefecture & $0.007 \%$ & $0.036 \%$ & $0.048 \%$ & $0.184 \%$ & $-0.041 \%$ & $-0.149 \%$ \\
\hline Kumamoto Prefecture & $0.007 \%$ & $0.017 \%$ & $0.017 \%$ & $0.035 \%$ & $-0.009 \%$ & $-0.017 \%$ \\
\hline Kyoto Prefecture & $0.007 \%$ & $0.023 \%$ & $0.034 \%$ & $0.098 \%$ & $-0.027 \%$ & $-0.075 \%$ \\
\hline Miyagi Prefecture & $0.003 \%$ & $0.007 \%$ & $0.006 \%$ & $0.011 \%$ & $-0.003 \%$ & $-0.004 \%$ \\
\hline Nagano Prefecture & $0.002 \%$ & $0.005 \%$ & $0.008 \%$ & $0.013 \%$ & $-0.006 \%$ & $-0.008 \%$ \\
\hline Niigata Prefecture & $0.006 \%$ & $0.016 \%$ & $0.022 \%$ & $0.043 \%$ & $-0.016 \%$ & $-0.027 \%$ \\
\hline Oita Prefecture & $0.007 \%$ & $0.017 \%$ & $0.016 \%$ & $0.027 \%$ & $-0.009 \%$ & $-0.011 \%$ \\
\hline Okayama Prefecture & $0.009 \%$ & $0.024 \%$ & $0.022 \%$ & $0.041 \%$ & $-0.013 \%$ & $-0.017 \%$ \\
\hline Osaka Prefecture & $0.005 \%$ & $0.023 \%$ & $0.027 \%$ & $0.098 \%$ & $-0.022 \%$ & $-0.076 \%$ \\
\hline Saitama Prefecture & $0.006 \%$ & $0.025 \%$ & $0.037 \%$ & $0.133 \%$ & $-0.030 \%$ & $-0.108 \%$ \\
\hline Shimane Prefecture & $0.005 \%$ & $0.012 \%$ & $0.019 \%$ & $0.051 \%$ & $-0.014 \%$ & $-0.039 \%$ \\
\hline Shizuoka Prefecture & $0.008 \%$ & $0.030 \%$ & $0.048 \%$ & $0.159 \%$ & $-0.040 \%$ & $-0.130 \%$ \\
\hline Tochigi Prefecture & $0.009 \%$ & $0.024 \%$ & $0.026 \%$ & $0.046 \%$ & $-0.016 \%$ & $-0.022 \%$ \\
\hline Tokushima Prefecture & $0.009 \%$ & $0.023 \%$ & $0.023 \%$ & $0.042 \%$ & $-0.014 \%$ & $-0.019 \%$ \\
\hline Yamanashi Prefecture & $0.010 \%$ & $0.025 \%$ & $0.015 \%$ & $0.028 \%$ & $-0.006 \%$ & $-0.003 \%$ \\
\hline Tokyo Metropolitan & $0.007 \%$ & $0.034 \%$ & $0.053 \%$ & $0.224 \%$ & $-0.045 \%$ & $-0.190 \%$ \\
\hline Chiba City & $0.007 \%$ & $0.016 \%$ & $0.022 \%$ & $0.043 \%$ & $-0.016 \%$ & $-0.027 \%$ \\
\hline Fukuoka City & $0.009 \%$ & $0.029 \%$ & $0.044 \%$ & $0.138 \%$ & $-0.035 \%$ & $-0.108 \%$ \\
\hline Hamamatsu City & $0.011 \%$ & $0.028 \%$ & $0.016 \%$ & $0.028 \%$ & $-0.004 \%$ & $0.000 \%$ \\
\hline Hiroshima City & $0.006 \%$ & $0.015 \%$ & $0.021 \%$ & $0.042 \%$ & $-0.015 \%$ & $-0.027 \%$ \\
\hline Kawasaki City & $0.011 \%$ & $0.036 \%$ & $0.060 \%$ & $0.167 \%$ & $-0.049 \%$ & $-0.131 \%$ \\
\hline Kita Kyushu City & $0.013 \%$ & $0.035 \%$ & $0.058 \%$ & $0.112 \%$ & $-0.045 \%$ & $-0.077 \%$ \\
\hline Kobe City & $0.011 \%$ & $0.033 \%$ & $0.055 \%$ & $0.155 \%$ & $-0.044 \%$ & $-0.122 \%$ \\
\hline Kyoto City & $0.009 \%$ & $0.033 \%$ & $0.046 \%$ & $0.141 \%$ & $-0.036 \%$ & $-0.108 \%$ \\
\hline Nagoya City & $0.010 \%$ & $0.035 \%$ & $0.064 \%$ & $0.194 \%$ & $-0.054 \%$ & $-0.159 \%$ \\
\hline Niigata City & $0.012 \%$ & $0.030 \%$ & $0.017 \%$ & $0.031 \%$ & $-0.006 \%$ & $-0.001 \%$ \\
\hline Okayama City & $0.008 \%$ & $0.019 \%$ & $0.009 \%$ & $0.015 \%$ & $-0.001 \%$ & $0.004 \%$ \\
\hline Osaka City & $0.008 \%$ & $0.029 \%$ & $0.043 \%$ & $0.157 \%$ & $-0.035 \%$ & $-0.128 \%$ \\
\hline Sakai City & $0.012 \%$ & $0.031 \%$ & $0.053 \%$ & $0.123 \%$ & $-0.040 \%$ & $-0.092 \%$ \\
\hline Saitama City & $0.007 \%$ & $0.014 \%$ & $0.016 \%$ & $0.030 \%$ & $-0.010 \%$ & $-0.016 \%$ \\
\hline Sapporo City & $0.008 \%$ & $0.027 \%$ & $0.043 \%$ & $0.133 \%$ & $-0.034 \%$ & $-0.106 \%$ \\
\hline Sendai City & $0.003 \%$ & $0.006 \%$ & $0.007 \%$ & $0.013 \%$ & $-0.005 \%$ & $-0.006 \%$ \\
\hline Shizuoka City & $0.006 \%$ & $0.012 \%$ & $0.011 \%$ & $0.020 \%$ & $-0.006 \%$ & $-0.009 \%$ \\
\hline Yokohama City & $0.010 \%$ & $0.038 \%$ & $0.062 \%$ & $0.210 \%$ & $-0.053 \%$ & $-0.172 \%$ \\
\hline Joint Local & $0.003 \%$ & $0.011 \%$ & $0.017 \%$ & $0.041 \%$ & $-0.014 \%$ & $-0.031 \%$ \\
\hline
\end{tabular}


To examine the RMSE and MaxAE of the NSS model in more detail, Table 3 shows the mean of the RMSE for each maturity. This table shows that the error for the longer term, over 10 years, is more than $0.1 \%$. As in the case of Tokyo Metropolitan in section 4.1, the fitness of the NSS model is less suited over the longer term. Some local governments have issued a small number of longer bonds, such as 20 or 30 year bonds, causing the NSS model to be less suited. The RMSE of the NSS model for bonds less than 10 year is less than $0.02 \%$, which is quite small in comparison to the BS model's case.

Table 3. Mean of the RMSE of the NSS fitted curve for each maturity

\begin{tabular}{|c|c|c|c|c|c|c|c|c|}
\hline \multirow[b]{2}{*}{ Issuer } & \multicolumn{8}{|c|}{ Maturity } \\
\hline & $0-2$ year & 2-4 year & 4-6 year & 6-8 year & $8-10$ year & $10-15$ year & $15-20$ year & 20-30 year \\
\hline Aichi Prefecture & $0.018 \%$ & $0.012 \%$ & $0.015 \%$ & $0.026 \%$ & $0.025 \%$ & $0.073 \%$ & $0.103 \%$ & $0.182 \%$ \\
\hline Chiba Prefecture & $0.014 \%$ & $0.011 \%$ & $0.017 \%$ & $0.025 \%$ & $0.022 \%$ & $0.067 \%$ & $0.104 \%$ & $0.150 \%$ \\
\hline Fukui Prefecture & $0.009 \%$ & $0.007 \%$ & $0.011 \%$ & $0.015 \%$ & $0.011 \%$ & $0.009 \%$ & $0.094 \%$ & $0.129 \%$ \\
\hline Fukuoka Prefecture & $0.013 \%$ & $0.012 \%$ & $0.015 \%$ & $0.027 \%$ & $0.026 \%$ & $0.073 \%$ & $0.098 \%$ & $0.181 \%$ \\
\hline Fukushima Prefecture & $0.005 \%$ & $0.008 \%$ & $0.010 \%$ & $0.018 \%$ & $0.021 \%$ & $0.006 \%$ & - & - \\
\hline Gifu Prefectureecture & $0.006 \%$ & $0.011 \%$ & $0.021 \%$ & $0.018 \%$ & $0.015 \%$ & $0.011 \%$ & - & - \\
\hline Gumma Prefecture & $0.008 \%$ & $0.008 \%$ & $0.012 \%$ & $0.019 \%$ & $0.018 \%$ & $0.045 \%$ & $0.099 \%$ & $0.123 \%$ \\
\hline Hiroshima Prefecture & $0.016 \%$ & $0.014 \%$ & $0.020 \%$ & $0.028 \%$ & $0.022 \%$ & $0.066 \%$ & $0.112 \%$ & $0.136 \%$ \\
\hline Hokkaido Prefecture & $0.012 \%$ & $0.010 \%$ & $0.014 \%$ & $0.023 \%$ & $0.025 \%$ & $0.052 \%$ & $0.100 \%$ & $0.116 \%$ \\
\hline Hyogo Prefecture & $0.014 \%$ & $0.013 \%$ & $0.016 \%$ & $0.026 \%$ & $0.025 \%$ & $0.066 \%$ & $0.106 \%$ & $0.196 \%$ \\
\hline Kagoshima Prefecture & $0.003 \%$ & $0.007 \%$ & $0.006 \%$ & $0.021 \%$ & - & - & - & - \\
\hline Kanagawa Prefecture & $0.014 \%$ & $0.011 \%$ & $0.015 \%$ & $0.026 \%$ & $0.023 \%$ & $0.072 \%$ & $0.105 \%$ & $0.189 \%$ \\
\hline Kumamoto Prefecture & $0.006 \%$ & $0.009 \%$ & $0.013 \%$ & $0.022 \%$ & $0.020 \%$ & $0.032 \%$ & - & - \\
\hline Kyoto Prefecture & $0.012 \%$ & $0.010 \%$ & $0.016 \%$ & $0.028 \%$ & $0.021 \%$ & $0.058 \%$ & $0.108 \%$ & $0.141 \%$ \\
\hline Miyagi Prefecture & $0.005 \%$ & $0.006 \%$ & $0.005 \%$ & $0.011 \%$ & $0.007 \%$ & $0.009 \%$ & - & - \\
\hline Nagano Prefecture & $0.005 \%$ & $0.006 \%$ & $0.007 \%$ & $0.016 \%$ & $0.022 \%$ & - & - & - \\
\hline Niigata Prefecture & $0.009 \%$ & $0.013 \%$ & $0.017 \%$ & $0.023 \%$ & $0.024 \%$ & $0.042 \%$ & - & - \\
\hline Oita Prefecture & $0.006 \%$ & $0.008 \%$ & $0.017 \%$ & $0.016 \%$ & $0.013 \%$ & $0.017 \%$ & - & - \\
\hline Okayama Prefecture & $0.005 \%$ & $0.011 \%$ & $0.024 \%$ & $0.024 \%$ & $0.015 \%$ & $0.054 \%$ & - & - \\
\hline Osaka Prefecture & $0.013 \%$ & $0.012 \%$ & $0.016 \%$ & $0.025 \%$ & $0.023 \%$ & $0.046 \%$ & $0.114 \%$ & $0.149 \%$ \\
\hline Saitama Prefecture & $0.017 \%$ & $0.013 \%$ & $0.017 \%$ & $0.025 \%$ & $0.022 \%$ & $0.070 \%$ & $0.099 \%$ & $0.219 \%$ \\
\hline Shimane Prefecture & $0.004 \%$ & $0.007 \%$ & $0.010 \%$ & $0.014 \%$ & $0.013 \%$ & $0.017 \%$ & - & $0.147 \%$ \\
\hline Shizuoka Prefecture & $0.015 \%$ & $0.013 \%$ & $0.017 \%$ & $0.027 \%$ & $0.026 \%$ & $0.074 \%$ & $0.094 \%$ & $0.186 \%$ \\
\hline Tochigi Prefecture & - & $0.005 \%$ & $0.036 \%$ & $0.020 \%$ & $0.011 \%$ & - & - & - \\
\hline Tokushima Prefecture & - & $0.009 \%$ & $0.032 \%$ & $0.018 \%$ & $0.009 \%$ & - & - & - \\
\hline Yamanashi Prefecture & $0.008 \%$ & $0.010 \%$ & $0.019 \%$ & $0.013 \%$ & $0.009 \%$ & $0.015 \%$ & - & - \\
\hline Tokyo Metropolitan & $0.015 \%$ & $0.012 \%$ & $0.017 \%$ & $0.026 \%$ & $0.024 \%$ & $0.071 \%$ & $0.101 \%$ & $0.184 \%$ \\
\hline Chiba City & $0.008 \%$ & $0.016 \%$ & $0.018 \%$ & $0.024 \%$ & $0.023 \%$ & $0.029 \%$ & - & - \\
\hline Fukuoka City & $0.013 \%$ & $0.010 \%$ & $0.014 \%$ & $0.026 \%$ & $0.025 \%$ & $0.071 \%$ & $0.103 \%$ & $0.173 \%$ \\
\hline Hamamatsu City & $0.007 \%$ & $0.012 \%$ & $0.019 \%$ & $0.014 \%$ & $0.009 \%$ & - & - & - \\
\hline Hiroshima City & $0.008 \%$ & $0.011 \%$ & $0.016 \%$ & $0.023 \%$ & $0.023 \%$ & $0.031 \%$ & - & - \\
\hline Kawasaki City & $0.014 \%$ & $0.011 \%$ & $0.015 \%$ & $0.031 \%$ & $0.028 \%$ & $0.063 \%$ & $0.104 \%$ & $0.186 \%$ \\
\hline Kita Kyushu City & $0.014 \%$ & $0.015 \%$ & $0.018 \%$ & $0.032 \%$ & $0.026 \%$ & $0.069 \%$ & $0.105 \%$ & $0.139 \%$ \\
\hline Kobe City & $0.014 \%$ & $0.012 \%$ & $0.016 \%$ & $0.027 \%$ & $0.028 \%$ & $0.080 \%$ & $0.104 \%$ & $0.181 \%$ \\
\hline Kyoto City & $0.012 \%$ & $0.011 \%$ & $0.015 \%$ & $0.029 \%$ & $0.027 \%$ & $0.069 \%$ & $0.102 \%$ & $0.184 \%$ \\
\hline Nagoya City & $0.015 \%$ & $0.014 \%$ & $0.017 \%$ & $0.027 \%$ & $0.026 \%$ & $0.079 \%$ & $0.099 \%$ & $0.187 \%$ \\
\hline Niigata City & $0.011 \%$ & $0.008 \%$ & $0.023 \%$ & $0.015 \%$ & $0.008 \%$ & $0.009 \%$ & - & - \\
\hline Okayama City & - & - & $0.011 \%$ & $0.009 \%$ & $0.004 \%$ & - & - & - \\
\hline Osaka City & $0.015 \%$ & $0.012 \%$ & $0.016 \%$ & $0.026 \%$ & $0.026 \%$ & $0.078 \%$ & $0.104 \%$ & $0.187 \%$ \\
\hline Sakai City & $0.022 \%$ & $0.016 \%$ & $0.020 \%$ & $0.020 \%$ & $0.020 \%$ & $0.055 \%$ & $0.092 \%$ & $0.152 \%$ \\
\hline Saitama City & $0.006 \%$ & $0.008 \%$ & $0.013 \%$ & $0.018 \%$ & $0.020 \%$ & $0.022 \%$ & - & - \\
\hline Sapporo City & $0.013 \%$ & $0.011 \%$ & $0.015 \%$ & $0.026 \%$ & $0.024 \%$ & $0.075 \%$ & $0.097 \%$ & $0.184 \%$ \\
\hline Sendai City & $0.006 \%$ & $0.006 \%$ & $0.007 \%$ & $0.017 \%$ & - & - & - & - \\
\hline Shizuoka City & $0.003 \%$ & $0.008 \%$ & $0.009 \%$ & $0.015 \%$ & $0.009 \%$ & $0.006 \%$ & - & - \\
\hline Yokohama City & $0.015 \%$ & $0.012 \%$ & $0.016 \%$ & $0.027 \%$ & $0.025 \%$ & $0.070 \%$ & $0.099 \%$ & $0.191 \%$ \\
\hline Joint Local & $0.009 \%$ & $0.009 \%$ & $0.013 \%$ & $0.018 \%$ & $0.020 \%$ & $0.040 \%$ & - & - \\
\hline
\end{tabular}

Note. "-" means there are no data in that grid. 


\section{Conclusion}

In this study, we have estimated the Japanese Municipal Bond yield curve using B-spline and the Nelson-Siegel-Svensson approach. As in previous studies, such as Kikuchi and Shintani (2012), the B-spline method fit quite well for Japan's Municipal Bonds, however, the fit of the NSS method was not always well suited, especially in terms of longer bond durations.

Our par yield estimation contributes significantly to academic and practitioner literature. As far as we know, no estimated par yield of Japan's municipal bond market is available that looks at daily frequency over 10 years. Bloomberg does provide the par yield of municipal bonds in Japan, however, the coverage of the Bloomberg data from 2002 to the present is quite limited (e.g., Tokyo Metropolitan), and only subscribers to Bloomberg have access to the Bloomberg data. Our full data set is available from http://www.mennns77.net, and will be updated regularly.

\section{Acknowledgments}

We would like to thank Koji Matsumoto for technical support. We also thank Hajime Fujiwara (Financial Service Agency), Kohei Shintani (Bank of Japan), and Toshiaki Watanabe (Hitotsubashi University) for their helpful comments. The views expressed in this paper are those of the authors and not any affiliations. Two authors contributed equally to this work.

\section{References}

Bank for International Settlements. (2005). Zero-coupon Yield Curves: Technical Documentation. BIS paper, 25. Retrieved from http://www.bis.org/publ/bppdf/bispap25.pdf

Fisher, M., Nychka, D. W., \& Zervos, D. (1995). Fitting the Term Structure of Interest Rates with Smoothing Splines. Federal Reserve System Working Paper.

Fujii, M., \& Takaoka, M. (2007). The term structure and the macroeconomy: An application of the Nelson-Siegel model. FSA Research Review, 4.

Gürkaynak, R. S., Sack, B., \& Wright, J. (2007). The U.S. Treasury Yield Curve: 1961 to the Present. Journal of Monetary Economics, 54(8), 2291-2304. http://dx.doi.org/10.1016/j.jmoneco.2007.06.029

Hattori, T., \& Miyake, H. (2015). Empirical Analysis of Yield Determinants in Japan's Municipal Bond Market: Does Credit Risk Premium Exist? MPRA Paper, 67127. Retrieved from https://mpra.ub.uni-muenchen.de/67127/1/MPRA_paper_67127.pdf

Ioannides, M. (2003). A Comparison of Yield Curve Estimation Techniques Using UK Data. Journal of Banking and Finance, 27(1), 1-26. http://dx.doi.org/10.1016/S0378-4266(01)00217-5

Kalev, P. S. (2004). Estimating and Interpreting Zero Coupon and Forward Rates: Australia, 1992-2001. Working Paper, Monach University. http://dx.doi.org/10.2139/ssrn.495702

Kawasaki, Y., \& Ando, T. (2005). Estimating Term Structure Using Non-linear Splines: A Penalized Likelihood Approach. In A. Zerger, \& R. M. Argent (Eds.), International Congress on Modelling and Simulation: Advances in Applications for Management and Decision Making (pp. 864-870).

Kikuchi, K., \& Shintani, K. (2012). Comparative Analysis of Zero Coupon Yield Curve Estimation Methods Using JGB Price Data. Institute for Monetary and Economic Studies, 12-E-04, Bank of Japan. Retrieved from http://www.imes.boj.or.jp/research/papers/english/12-E-04.pdf

Kladivko, K. (2010). The Czech Treasury Yield Curve from 1999 to the Present. The Czech Journal of Economics and Finance, 60(4), 307-335.

Komine, M., Yamagishi, M., Matsumoto, K., Futatsugi,T, Tsukasa, J., Nagao T., ... Sano, N. (1989). Wagakuni Saiken Shijou no Koyuu no Gensho to Kikan Kouzou Bunseki [Analyses of Japan's Bond Market and its Term Structure]. Financial Review, 14, Ministry of Finance (in Japanese).

McCulloch, J. H. (1975). The tax-adjusted yield curve. Journal of Finance, 30(3), 811-830. http://dx.doi.org/10.1111/j.1540-6261.1975.tb01852.x

McCulloch, J. H. (1990). U.S. term structure data: 1946-87. In B. M. Freidman, \& F. H. Han (Eds.), Handbook of Monetary Economics (Vol. 1, pp. 672-715). Elsevier Science.

Nelson, C. R., \& Siegel, A. F. (1987). Parsimonious Modeling of Yield Curves. Journal of Business, 60(4), 473-489. http://dx.doi.org/10.1086/296409

Oda, N. (1996). A Note on the Estimation of Japanese Government Bond Yield Curves. Institute for Monetary 
and Economic Studies, 96-E-27, Bank of Japan.

Steeley, J. M. (1991). Estimating the Gilt-edged Term Structure: Basis Splines and Confidence Intervals. Journal of Business Finance and Accounting, 18(4), 513-529. http://dx.doi.org/10.1111/j.1468-5957.1991.tb01119.x

Svensson, L. E. (1995). Estimating Forward Interest Rates with the Extended Nelson and Siegel Method. Sveriges Riksbank Quarterly Review, 3(1), 13-26.

Waggoner, D. F. (1997). Spline Methods for Extracting Interest Rate Curves from Coupon Bond Prices. Federal Reserve Bank of Atlanta Working Paper, 97-10.

\section{Notes}

Note 1. Bank of Japan, Flow of Funds. The dollar amount of Japan's municipal bond market is calculated based on the exchange rate as of the end of September (USD 1= 119.8 yen).

Note 2. Bank of Japan, Flow of Funds.

Note 3. Aichi, Fukuoka, Hyogo, Kanagawa, Osaka, Saitama, and Shizuoka prefectures, Tokyo metropolitan, and Yokohama city.

Note 4. Chiba, Hiroshima, Hokkaido, and Kyoto prefectures, Fukuoka, Kawasaki, Nagoya, Kyoto, Osaka, and Sapporo cities.

Note 5. The estimation results will be posted on the website "Hiroki Miyake: Market Data." The address is http://www.mennns77.net. Additionally, we have already been admitted into the Japan Securities Dealers Association [JSDA], the data source of our estimation.

Note 6. Bloomberg provides the evaluation service, BVAL. Based on the BVAL Curve, most of the par rates related to Japan's municipal bond appear to be available from April 2011 or July 2012 to the present, except for Tokyo Metropolitan.

Note 7. There could other classifications. For example, Kikuchi and Shintani (2012) classify the methods with more detail: (1) The Piecewise Polynominal Method, (2) Non-Parametric Method, (3) The Polynomial Method, and (4) Parsimonious Function Method.

Note 8. The NSS function has six parameters, so at least six sample issues are needed when we estimate the bond yield curve based on this functional form.

Note 9. This number could differ depending on the estimation date. One reason is that some local governments did not begin to issue the publicly offered municipal bonds until years later (e.g., Niigata City at the end of 2007). Another reason is that some local governments stopped issuing bonds temporarily or decreased their issuing frequency.

Note 10. The economists and the practitioners use the forward rate of government bonds or the interest swap in various situations such as understanding the market expectation of future interest rates or in pricing financial products.

\section{Copyrights}

Copyright for this article is retained by the authors, with first publication rights granted to the journal.

This is an open-access article distributed under the terms and conditions of the Creative Commons Attribution license (http://creativecommons.org/licenses/by/3.0/). 